\title{
Naphthalene Urea Derivatives for Anion Receptor: Effects of Substituents on Benzoate Binding
}

\author{
Hyun Ah Jeong, Eun Jin Cho, Hyoung Min Yeo, Byung Ju Ryu, and Kye Chun Nam* \\ Deparment of Chemistry, Chomam National Lniversity, Gwangiu 500-757, Korea. "E-mail: kchamachomamac.kr \\ Received Februarv 15, 2007
}

Key Words : Anion sensor. Substituent effect. Binding conștant. Naphthalene urea derivative

Anions play an important role in a wide range of chemical and biological processes. and considerable attention has been focused on the design of host molecules that can recognize and sense anion species selectively through the naked eye electrochemical and optical responses. ${ }^{1.2}$ Recently it has been reported that the optical anion receptors could be developed with aromatic moieties such as anthracene. antluraquinone. pyridinium and naphthalene. ${ }^{3-7}$ Those chemosensors are constructed according to the receptor-chromophore general binomial. which involves the binding a specific anion substrate with receptor sites and a chromophore responsible for translating the receptor-anion association into an optical signal. This variation can be related to either structural or conformational changes in the receptor structure when a complex is fomed or to the formation of a charge transfer complex ${ }^{8-11}$ As one type of important receptors. urea groups have been suited as fluorescent and color change receptors of anion sensors based on the hydrogenbonding mechanism. 12

By developing a relatively simple urea derivative from naphthalene moiety. the fluoride selective receptor for fluorescence has been reported in our group. ${ }^{13}$ which gave a unique fluorescence peak in the presence of fluoride ions. Also a following investigation have produced the several visible colorimetric fluoride ion sensors by introducing nitrophenyl and azo groups at the urea moiety. ${ }^{14}$

Four urea protons in naphthalene urea derivatives have provided the positive dipole for the anion binding. In order to examine the anion binding properties in detail fourteen naphthalene urea receptors have been synthesized and their anion binding properties were investigated from ${ }^{l} \mathrm{H}$ NMR titration.

\section{Results and Discussion}

Anion binding sites in naphthalene urea derivatives are in the area of urea groups. which provide the positive dipole due to the $\mathrm{N}-\mathrm{H}$ protons. Anions bind at the urea N-H protons by the ion-dipole interaction. The magnitude of the positive dipole primarily determined the anion binding strength. The electronic factor on<smiles>[R]NC(=O)Nc1cccc([X])c1NC(=O)N[R]</smiles>
urea $\mathrm{N}-\mathrm{H}$ protons can be influenced from the $\mathrm{R}$ and $\mathrm{X}$ groups on receptor. Electronically $\mathrm{R}$ groups can affect $\mathrm{H}_{\mathrm{b}}$ protons. on the other hand $\mathrm{X}$ group can influence the $\mathrm{H}_{4}$ protons more easily. By varying $\mathrm{R}$ groups 12 receptors (112) were prepared and two more receptors $(13,14)$ were sy'nthessized by nitrating ligand 2.

Synthesis. Ligands 1 to 12 were synthesized from the reaction of 1.8-diaminonaphthelene and the corresponding isocyanates in high yield. The urea ligands can be easily confirmed the structure from ${ }^{l} \mathrm{H}$ NMR spectrum of the ligands such as that the phenyl urea ligands shows two characteristic singlets at around $\delta 8-9 \mathrm{ppm}$ for the two different urea N-H protons and butyl urea (2) shows a triplet at $\delta 5.6 \mathrm{ppm}$ for the $\mathrm{N}-\mathrm{H}$ protons connecting to butyl group. From the nitration reaction of 2 . two receptors (13 and 14) have been prepared. By controlling the amount of the $\mathrm{KNO}_{3} /$ $\mathrm{AlCl}_{3}$ compound 13 and 14 also were obtained from treatment of 1.8-bis(N-butylureido)naphthalene 2 with $\mathrm{KNO}_{3} /$ $\mathrm{AlCl}_{3}$ in $\mathrm{CHCl}_{2}$. From the ${ }^{\mathrm{l}} \mathrm{H}$ NMR spectrum. 13 was identified as a dinitronaphthalene urea derivative. which shows a singlet and a triplet at $\delta 6.57$ and 7.08 for the four urea N-H protons and two doublets at $\delta 8.36$ and 8.18 for the four aromatic protons of naphthalene. In case of compound $\mathbf{1 4}$. ${ }^{\mathrm{l}} \mathrm{H}$ NMR spectrum shows two singlets at $\delta 9.78$ and 8.58 for the two urea $\mathrm{N}-\mathrm{H}$ protons connected to the naphthalene and two triplets at $\delta 7.14$ and 6.58 for the two urea N-H protons connected to the butyl group. Also. aromatic proton peaks of naphthalene were appeared as four doublets and one triplet at $\delta 8.25$ and 7.64 as expected from the mononitronaphthalene structure.

Binding Properties. ${ }^{3} \mathrm{H}$ NMR titration method has been applied for the binding constant determination and benzoate ion was used as an anion comparison. Fluoride ions were bound with ligands selectively. but the binding constants were too high for comparison.

Chemical shifts of $\mathrm{H}_{\mathrm{t}}$ and $\mathrm{H}_{\mathrm{t}}$ of ligand 1 are $\delta 9.01$ and $8.83 \mathrm{ppm}$ in the absence of anions. Addition of benzoate cause the downfield shift dramatically and then saturated after 1 equivalent of benzoate as shown in Figure 1. suggesting that ligand 1 bind with benzoate $1: 1$ ratio. Chemical shift of $\mathrm{NH}_{\mathrm{a}}$ changed from $\delta 9.01$ to $\delta 10.33 \mathrm{ppm}(\Delta \delta 1.32 \mathrm{ppm})$ and $\delta 8.83$ to $\delta 10.50 \mathrm{ppm}(\Delta \delta 1.67 \mathrm{ppm})$ for the $\mathrm{NH}_{\mathrm{t}}$ upon addition of 10 equivalents of benzoate. indicating that $\mathrm{NH}_{\mathrm{b}}$ protons contributed more strongly for the benzoate binding probably due to the steric factor.

Chenical shifts of $\mathrm{H}_{a}$ and $\mathrm{H}_{\mathrm{t}}$ for ligand 2 are $\delta 8.78$ and $6.70 \mathrm{ppm}$ in the absence of anions. Addition of benzoate cause the downfield shift and then saturated after 1 equival- 


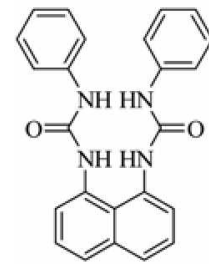

1

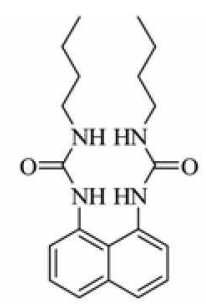

2

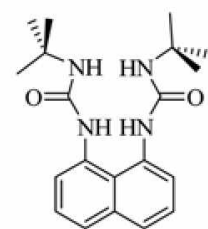

3

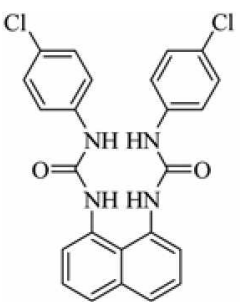

4

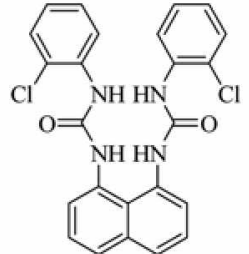

5

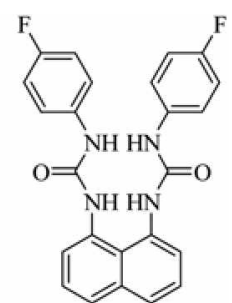

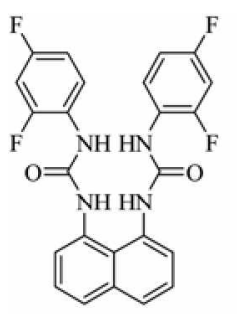

7

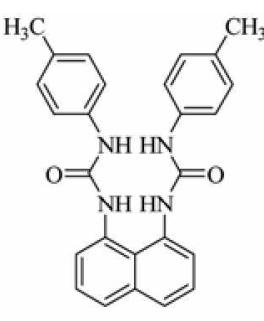

8

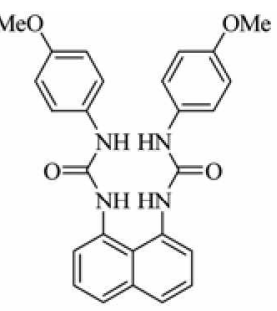

9

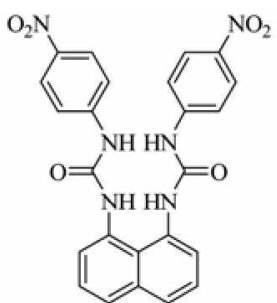

10

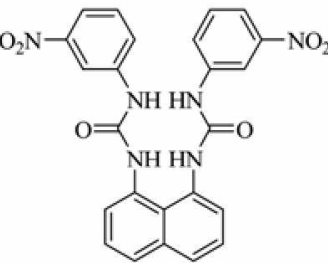

11

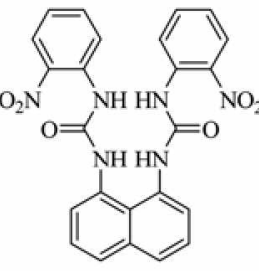

12

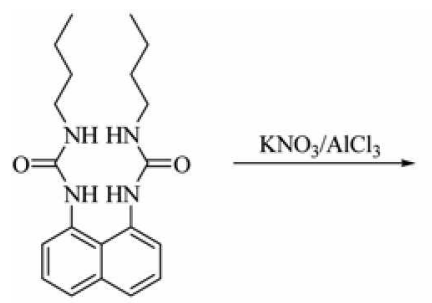

2<smiles>CCCCNC(=O)Nc1ccc([N+](=O)[O-])c2c([N+](=O)[O-])ccc(NC(=O)NCCCC)c12</smiles>

13

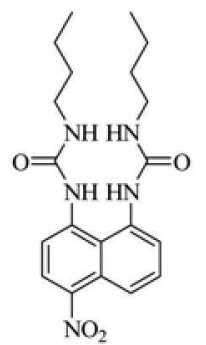

14

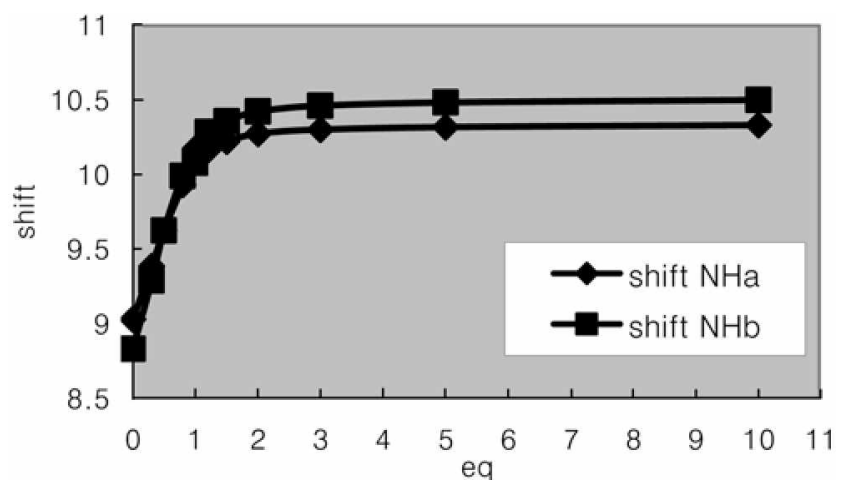

Figure 1. Chemical shifts changes of urea $\mathrm{H}_{\mathrm{a}}$ and $\mathrm{H}_{\mathrm{b}}$ protons for ligand 1 in the presence of benzoate ions.

ent of benzoate as shown in Figure 2, suggesting that ligand 2 bind with benzoate $1: 1$ ratio. Chemical shift of $\mathrm{NH}_{3}$ changed from $\delta 8.78$ to $\delta 10.40 \mathrm{ppm}(\Delta \delta 1.62 \mathrm{ppm})$ and $\delta$ 6.70 to $\delta 7.74 \mathrm{ppm}(\Delta \delta 1.04 \mathrm{ppm})$ for the $\mathrm{NH}_{\mathrm{b}}$ upon addition of 10 equivalents of benzoate. indicating that $\mathrm{NH}_{\mathrm{a}}$ protons contributed more strongly for the benzoate binding probably due to the electronic factor in this case. As expected from the bulky structure. chemical shifts of $\mathrm{H}_{\mathrm{b}}$ and $\mathrm{H}_{\mathrm{b}}$ for ligand 3 are hardly changed at all $(\delta 10.080 \sim \delta 10.085)$ upon addition of 10 equivalents of benzoate. Steric hindrance of t-butyl group inhibits the benzoate binding completely. From the same method all ligands were titrated and stability constants $\left(K_{a}\right)$

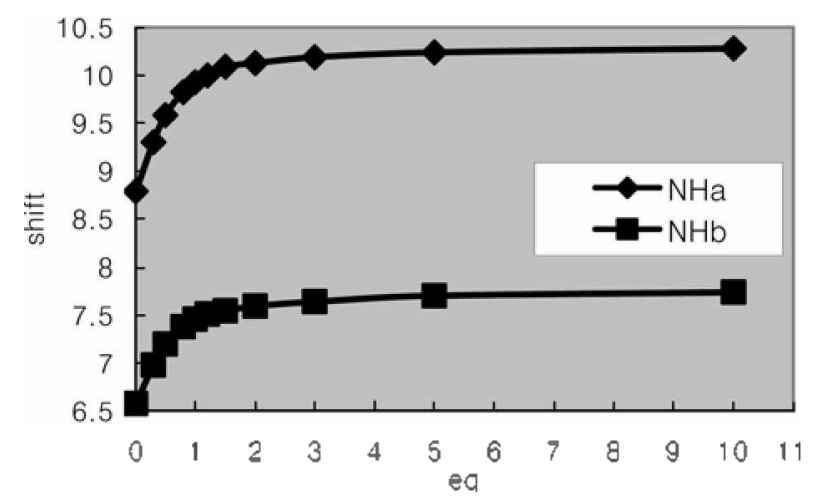

Figure 2. Chemical shitts changes of urea $H_{a}$ and $H_{b}$ protons for ligand 2 in the presence of benzoate ions.

were determined from the EQ NMR. ${ }^{15}$

Electron withdrawing groups such as chloro. fluoro. nitrophenyl strengthen the anion binding from the development of more positive charge on $\mathrm{N}-\mathrm{H}$ protons by pulling electron to urea group. Binding constant increase from 4.070 for 1 to 22.090 for 4 as can be seen in Table 1. A sinilar increase was observed for the ligands 6.10 and 11 as expected. Ligands 13 and 14 which possess the nitro groups in the naphthalene moiety could influence the $\mathrm{N}-\mathrm{H}$ protons. thus expecting high binding constant. but unfortunately due to the bad solubility of the ligands. $K_{a}$ could not be available. A qualitative investigation of binding constants from UV 
Table 1. Stability constants $\left(K_{a}\right)$ of the ligands in DMSO tor the benzoate ions

\begin{tabular}{ccccccccccccc}
\hline Ligands & $\mathbf{1}$ & $\mathbf{2}$ & $\mathbf{3}$ & $\mathbf{4}$ & $\mathbf{5}$ & $\mathbf{6}$ & $\mathbf{7}$ & $\mathbf{8}$ & $\mathbf{9}$ & $\mathbf{1 0}$ & $\mathbf{1 1}$ & $\mathbf{1 2}$ \\
\hline$K_{\sigma}$ & 4,070 & 2,870 & $-^{\prime}$ & 22,050 & 2,240 & 19,530 & 1,310 & 3,790 & 3,360 & 13,710 & 6,190 & $-^{a}$ \\
Enor $(\%)$ & 11 & 14 & $-^{*}$ & 3 & 15 & 15 & 18 & 5 & 10 & 17 & 14 & $-{ }^{a}$ \\
\hline
\end{tabular}

"Too weak to measure. "Due to the bad solubility. $K_{a}$ was not obtained for the ligands 13 and 14

suggests a small increase the anion binding indicating that the $\mathrm{N}-\mathrm{H}_{\mathrm{a}}$ protons which could be influenced directly from naphthalene ring is less effective for participating the anion binding due to the geometric reason.

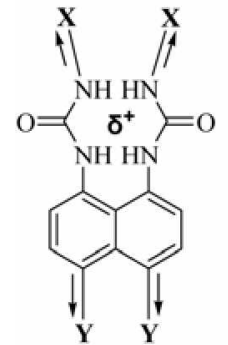

EWG
Increasc posilive charge for urea N.H Strenglhet the anion binding Weaken the anion binding

On the other hand. electron donating groups such as butyl. methylphenyl and methoxy phenyl weaken the anion binding from the development of less positive charge on $\mathrm{N} \cdot \mathrm{H}$ protons by donating electron to urea group. Binding constant decreases from 4.070 for $\mathbf{1}$ to 2.870 for 2 as can be seen in Table 1. A sumilar decrease was observed for the ligands 8 and 9 as expected. Bulky group such as t-butyl and orthosubstitution of the phenyl ring prevent anion binding significantly. It is quite interesting that $o$-substituted ligands such as 5 and 7 show a low binding constants and no binding for ligand 12. Otho substitution might cause a structural change of the ligands which play against an effective anion binding. Also the intramolecular H-bonds could play an important role in the case of $\mathbf{1 2}$. but no evidence was found at this moment. Chemical shift of $\mathrm{N}-\mathrm{H}_{\mathrm{b}}$ appear at $\delta 10.05$ $\mathrm{ppm}$ in the absence of anion. On the other hand. those of N$\mathrm{H}_{\mathrm{b}}$ are $\delta 9.36$ and 9.58 for ligands $\mathbf{1 1}$ and $\mathbf{1 0}$.

\section{Summary}

A simple reaction of 1.8-dianinonaphthalene and various isocyanates provides the important anion receptors. Electronic effect on the para position of the phenyl ring of the urea ligands do influence the anion binding significantly and nitration on naphthalene ring also influence the binding properties. but much less compared with the changes of other side of urea group due to the structural easiness of N$\mathrm{H}_{\mathrm{b}}$ protons for anion binding.

\section{Experimental}

1,8-Bis( $N$-phenylureido)naphthalene (1) ${ }^{11}$
1,8-Bis( $N$-butylureido)naphthalene (2). To a stirred solution $0.2 \mathrm{~g}(1.26 \mathrm{mmol})$ of 1.8-diaminonaphthalene in 30 $\mathrm{mL}$ of THF/DMF (2:1 ratio), $0.55 \mathrm{~mL}(5.20 \mathrm{mmol})$ of butyl isocyanate in THF $15 \mathrm{~mL}$ was added and the reaction mixture was refluxed for 24 hours under the nitrogen atmosphere. The precipitate was occurred in reaction mixture. The reaction mixture was cooled and filtered. The precipitate was washed with $\mathrm{MeOH}(100 \mathrm{~mL})$ and filtered to give 0.35 $\mathrm{g}\left(78 \%\right.$ ) of 2. mp $195^{\circ} \mathrm{C}$, decomp.; ${ }^{1} \mathrm{H}$ NMR (DMSO-d 6 10.05 (s. 2H. NH), 7.21 (t. $2 \mathrm{H}$. ArH. $J=8.5 \mathrm{~Hz}$ ), 7.10 (d, $2 \mathrm{H}$. ArH. $J=8.5 \mathrm{~Hz}$ ). $6.5 \mathrm{l}$ (d. $2 \mathrm{H}$. ArH, $J=8.0 \mathrm{~Hz}$ ). 5.69 (t, $2 \mathrm{H}$. NH. $J=3.3 \mathrm{~Hz}), 2.96\left(\mathrm{~m} .4 \mathrm{H}\right.$. $-\mathrm{CH}_{2}-\mathrm{)} .1 .29(\mathrm{~m}, 8 \mathrm{H}$, $-\mathrm{CH}_{2} \mathrm{CH}_{2}-0.86$ (t, $\left.6 \mathrm{H} . \quad-\mathrm{CH}_{3}, J=4.2 \mathrm{~Hz}\right):{ }^{13} \mathrm{C}$ NMR $\left(\mathrm{DMSO}-\mathrm{d}_{6}\right) \delta 158.3(-\mathrm{CO}), 150.3,137.8,134.3,128.2$, 117.8, 113.8, 104.2 (Ar). 39.0, 32.4. $19.7\left(-\mathrm{CH}_{2}=\right) .13 .9$ $\left(-\mathrm{CH}_{3}\right) ; \mathrm{FAB}$ MS $m: 257(\mathrm{M}+\mathrm{l}$, Calcd 357). Anal. Calcd for $\mathrm{C}_{21} \mathrm{H}_{2 \times} \mathrm{N}_{4} \mathrm{O}_{2}: \mathrm{C}, 67.42: \mathrm{H} .7 .86 ; \mathrm{N}, 15.73$. Found: C. 67.40. H. $7.80 ;$ N. 15.68 .

1,8-Bis( $N$-t-butylureido)naphthalene (3). To a stirred solution $0.2 \mathrm{~g}(1.26 \mathrm{mmol})$ of 1.8-diaminonaphthalene in 30 $\mathrm{mL}$ of THF/DMF (2:1 ratio), $0.33 \mathrm{~mL}(2.93 \mathrm{mmol})$ of $t e n-$ butyl isocyanate in THF $15 \mathrm{~mL}$ was added and the reaction mixture was refluxed for 3 days under the nitrogen atmosphere. The precipitate was occurred in reaction mixture. The reaction mixture was cooled and filtered. The precipitate was washed with acetone $(100 \mathrm{~mL})$ and filtered to give 0.40 $\mathrm{g}(89 \%)$ of 3. mp $247^{\circ} \mathrm{C}$, decomp. ${ }^{1} \mathrm{H}$ NMR (DMSO-d $\delta$ 10.07 (s, $2 \mathrm{H}$. NH), 7.20 (t. $2 \mathrm{H}$. ArH. $J=8.4 \mathrm{~Hz}$ ). 7.10 (d, $2 \mathrm{H}$. ArH. $J=7.5 \mathrm{~Hz}$ ), $6.5 \mathrm{l}$ (d. $2 \mathrm{H}, \mathrm{ArH} . J=7.2 \mathrm{~Hz}$ ). 5.44 (s. $2 \mathrm{H} . \mathrm{NH}$ ). 1.18 (s. $\left.18 \mathrm{H},-\mathrm{C}\left(\mathrm{CH}_{3}\right)_{2}\right)$.

1,8-Bis( $N$-4-chlorophenylureido)naphthalene (4). Following the procedure described for ligand $2.0 .2 \mathrm{~g}(1.26$ mumol) of 1.8-diaminonaphthalene and $0.45 \mathrm{~g}(2.91 \mathrm{mmol})$ of 4-chlorophenyl isocyanate produced $0.52 \mathrm{~g}(89 \%)$ of 4 . mp $293^{\circ} \mathrm{C}$, decomp: ${ }^{\mathrm{i}} \mathrm{H}$ NMR (DMSO-d 6 ) $\delta 9.11$ (s. $2 \mathrm{H}$, $\mathrm{NH}), \delta 8.79(\mathrm{~s}, 2 \mathrm{H}, \mathrm{NH}), \delta 7.75(\mathrm{~d}, 2 \mathrm{H}, \mathrm{ArH}, J=7.8 \mathrm{~Hz}), \delta$ 7.65 (d. $2 \mathrm{H}, \mathrm{ArH}, J=6.6 \mathrm{~Hz}$ ) $\delta 7.48$ (t. $2 \mathrm{H}, \mathrm{ArH} . J=7.8$ $\mathrm{Hz}), \delta 7.4 \mathrm{l}(\mathrm{d} .4 \mathrm{H}, \mathrm{ArH}, J=9.0 \mathrm{~Hz}), \delta 7.24$ (d. $4 \mathrm{H}, \mathrm{ArH}, J=$ $8.7 \mathrm{~Hz})$.

1,8-Bis( $N$-2-chlorophenylureido)naphthalene (5). Following the procedure described for ligand $2.0 .2 \mathrm{~g}(1.26$ mmol) of 1.8-diaminonaphthalene and $0.35 \mathrm{~mL}(2.91 \mathrm{mmol})$ of 2-chlorophenyl isocyanate gave $0.56 \mathrm{~g}(95 \%)$ of $5 \mathrm{mp}$ $276^{\circ} \mathrm{C}$, decomp.: ' $\mathrm{H}$ NMR (DMSO-d 6$) \delta 9.28(\mathrm{~s}, 2 \mathrm{H}$. NH), $8.46(\mathrm{~s}, 2 \mathrm{H} . \mathrm{NH}) .8 .14$ (d. $2 \mathrm{H}, \mathrm{ArH}, J=8.4 \mathrm{~Hz}) .7 .75$ (d. $2 \mathrm{H}$, ArH. $J=8.4 \mathrm{~Hz}$ ). 7.62 (d. $2 \mathrm{H}$, ArH. $J=7.2 \mathrm{~Hz}$ ). $7.48(\mathrm{t} .2 \mathrm{H}$. $\operatorname{ArH}, J=7.8 \mathrm{~Hz}$ ). 7.34 (d. $2 \mathrm{H}, \mathrm{ArH}, J=8.1 \mathrm{~Hz}$ ). 7.31 (t. $2 \mathrm{H}$. ArH, $J=7.8 \mathrm{~Hz}$ ), 6.93 (t. $2 \mathrm{H}, \mathrm{ArH}, J=8.4 \mathrm{~Hz}$ ): ${ }^{13} \mathrm{C}$ NMR $($ DMSO-d 6$) \delta 152.9(-\mathrm{CO}), 136.4,135.7,133.4,128.9$. 127.2, 125.5. 125.4. 123.0. 122.7. 121.8. 121.3(Ar). 
1,8-Bis( $N$-t-fluorophenylureido)naphthalene (6). Following the procedure described for ligand $2.0 .2 \mathrm{~g}(1.26$ $\mathrm{mmol})$ of 1.8-diaminonaphthalene and $0.33 \mathrm{~mL}(2.91 \mathrm{mmol})$ of 4-fluorophenyl isocyanate gave $0.52 \mathrm{~g}(95 \%)$ of $6 \mathrm{mp}$ $287^{\circ} \mathrm{C}$. decomp.: ${ }^{1} \mathrm{H}$ NMR (DMSO-d 6 ) $\delta 9.02$ (s. 2H. NH). 8.78 (s, 2H. NH). 7.72 (d, 2H. ArH. $J=8.1$ Hz). 7.65 (d, $2 \mathrm{H}$. $\mathrm{ArH}, J=7.2 \mathrm{~Hz}), 7.46($ d. $2 \mathrm{H}, \mathrm{ArH}, J=7.8 \mathrm{~Hz}), 7.39(\mathrm{~m}$. $4 \mathrm{H}, \mathrm{ArH}$ ). 7.04 (t. $4 \mathrm{H}$, ArH. $J=9.0 \mathrm{~Hz}$ ).

1,8-Bis $(N$-2,t-difluorophenylureido)naphthalene (7). Following the procedure described for ligand $2.0 .2 \mathrm{~g}(1.26$ $\mathrm{mmol})$ of 1.8 -diaminonaphthalene and $0.31 \mathrm{~mL}(2.91 \mathrm{mmol})$ of 2.4-difluorophenyl isocyanate gave $0.50 \mathrm{~g}(84 \%)$ of $7 . \mathrm{mp}$ $271{ }^{\circ} \mathrm{C}$. decomp.: ${ }^{1} \mathrm{H}$ NMR (DMSO-d 6 ) $\delta 8.95$ (s. $2 \mathrm{H}$. NH). 8.72 (s, $2 \mathrm{H}, \mathrm{NH}$ ), 8.07 (m. $2 \mathrm{H}, \mathrm{ArH}), 7.75$ (d. $2 \mathrm{H}, \mathrm{ArH}, J=$ $7.8 \mathrm{~Hz}), 7.60(\mathrm{~d}, 2 \mathrm{H} . \mathrm{ArH}, J=7.8 \mathrm{~Hz}), 7.47(\mathrm{t}, 2 \mathrm{H}, \mathrm{ArH} . J=$ $7.8 \mathrm{~Hz}), 7.18(\mathrm{t}, 2 \mathrm{H}, \mathrm{ArH}, J=9.3 \mathrm{~Hz}), 7.69(\mathrm{t}, 2 \mathrm{H}, \mathrm{ArH} . J=$ $9.0 \mathrm{~Hz})$.

1,8-Bis( $N$-4-methylphenylureido)naphthalene (8). Following the procedure described for ligand $2,0.2 \mathrm{~g}(1.26$ $\mathrm{mmol})$ of 1.8-dianinonaphthalene and $0.37 \mathrm{~mL}(2.91 \mathrm{mmol})$ of 4-tolyl isocyanate gave $0.45 \mathrm{~g}(84 \%)$ of 8 . mp $247^{\circ} \mathrm{C}$. decomp.; ${ }^{1} \mathrm{H}$ NMR (DMSO-d $) ~ \delta 8.82$ (s, 2H. NH), 8.75 (s. $2 \mathrm{H}$. NH). $\delta 7.70$ (d. $2 \mathrm{H}$. ArH. $J=7.5 \mathrm{~Hz}$ ). 7.65 (d. $2 \mathrm{H}, \mathrm{ArH}$. $J=8.1 \mathrm{~Hz}$ ), 7.42 (t. $2 \mathrm{H}$. ArH. $J=7.5 \mathrm{~Hz}$ ). 7.29 (d. $4 \mathrm{H}, \mathrm{ArH}$. $J=8.1 \mathrm{~Hz}), 7.01(\mathrm{~d}, 4 \mathrm{H}, \mathrm{ArH}, J=8.1 \mathrm{~Hz}), \delta 2.24(\mathrm{~s}, 6 \mathrm{H}$. $-\mathrm{CH}_{3}$ ).

1,8-Bis( $N$-4-methoxyphenylureido)naphthalene (9). Following the procedure described for ligand $2,0.2 \mathrm{~g}(1.26$ $\mathrm{mmol}$ ) of 1.8 -diaminonaphthalene and $0.38 \mathrm{~mL}(2.91 \mathrm{~mm}$ of 4-methoxyphenyl isocyanate gave $0.40 \mathrm{~g}(69 \%)$ of $9 . \mathrm{mp}$ $280^{\circ} \mathrm{C}$. decomp.: ${ }^{\mathrm{i}} \mathrm{H}$ NMR (DMSO-d 6 ) $\delta 8.76$ (s. $2 \mathrm{H}$. NH). 8.75 (s, 2H. NH). 7.70 (d, 2H. ArH. $J=7.8$ Hz). 7.66 (d, $2 \mathrm{H}$. ArH, $J=8.1 \mathrm{~Hz}) .7 .42(\mathrm{t}, 2 \mathrm{H} . \mathrm{ArH}, J=7.8 \mathrm{~Hz}), 7.3 \mathrm{l}(\mathrm{d},+\mathrm{H}$. $\mathrm{ArH}, J=9.0 \mathrm{~Hz}), 6.79$ (d. $4 \mathrm{H}, \mathrm{ArH} . J=9.0 \mathrm{~Hz}) .2 .24(\mathrm{~s}, 6 \mathrm{H}$. $\left.-\mathrm{OCH}_{3}\right)$

1,8-Bis( $N$-4-nitrophenylureido)naphthalene $(10)^{12}$

1,8-Bis $\left(N-3\right.$-nitrophenylureido)naphthalene (11) ${ }^{12}$

1,8-Bis( $N$-2-nitrophenylureido)naphthalene

(12). Following the procedure described for ligand $2.0 .20 \mathrm{~g}(1.26$ mmol) of 1.8-diaminonaphthalene and $0.48 \mathrm{~g}(2.92 \mathrm{mmol})$ of 2-nitrophenyl isocyanate gave a yellow powder $0.60 \mathrm{~g}$ (98\%) of 12 mp $242-244{ }^{\circ} \mathrm{C} \cdot{ }^{-1} \mathrm{H}$ NMR (DMSO-d $) \delta 10.05$ (s. $2 \mathrm{H}, \mathrm{NH}) . \delta 7.95(\mathrm{~d}, 2 \mathrm{H} . \mathrm{ArH}, J=8.7 \mathrm{~Hz}), \delta 7.39(\mathrm{t}, 4 \mathrm{H}$. ArH and $\mathrm{NH}, J=7.0 \mathrm{~Hz}$ ). $\delta 7.20$ (t. $2 \mathrm{H}$. ArH, $J=8.4 \mathrm{~Hz}$ ), $\delta$ 7.10 (d. $2 \mathrm{H}$. $\mathrm{ArH}, J=7.8 \mathrm{~Hz}$ ), $\delta 7.0$ (d. $2 \mathrm{H}$. ArH, $J=8.4$ $\mathrm{Hz}), \delta 6.61$ (t. $2 \mathrm{H} . \mathrm{ArH}, J=6.6 \mathrm{~Hz}) . \delta 6.5 \mathrm{l}(\mathrm{d}, 2 \mathrm{H}, \mathrm{ArH}, J=$ $7.2 \mathrm{~Hz})$. FAB MS $m z 486(\mathrm{M}+1$, Calcd 487). Anal. Calcd for $\mathrm{C}_{34} \mathrm{H}_{18} \mathrm{~N}_{6} \mathrm{O}_{6}$ : C, $59.26 \mathrm{H} .3 .73 \mathrm{~N}, 17.28$. Found: C. 59.20 H. 3.80 N. 17.13

1,8-Bis( $N$-butỵlureido)-4,5-dinitronaphthalene (13). To a solution of 1,8-bis $(N$-butylureido)naphthalene $2(0.10 \mathrm{~g}$. 0.28 mmol) in dried $\mathrm{CH}_{2} \mathrm{Cl}_{2} 20 \mathrm{~mL}$ was added potassium nitrate $0.34 \mathrm{~g}(3.36 \mathrm{mmol})$ and aluminium chloride $0.67 \mathrm{~g}$ $(5.04 \mathrm{mmol})$ and the reaction mixture was stirred 2 hours in $0^{\circ} \mathrm{C}$ and stirred at the room temperature for 24 hours. The residue was treated with $5 \% \mathrm{HCl} 100 \mathrm{~mL}$. The precipitate was filtered to give $0.08 \mathrm{~g}(64 \%)$ of $13 . \mathrm{mp} 195^{\circ} \mathrm{C}$. decomp. ${ }^{\mathrm{J}} \mathrm{H}$ NMR (DMSO-d $) \delta 9.26$ (s. 2H. NH). 8.36 (d. $2 \mathrm{H}, \mathrm{ArH}$, $J=9.0 \mathrm{~Hz}), 8.18(\mathrm{~d}, 2 \mathrm{H}$. ArH. $J=9.0 \mathrm{~Hz}) .7 .08$ (t. $2 \mathrm{H}, \mathrm{NH}, J$ $=5.2 \mathrm{~Hz}) .3 .12\left(\mathrm{~m} .4 \mathrm{H} .-\mathrm{CH}_{2}-\right), 1.35\left(\mathrm{~m}, 8 \mathrm{H} .-\mathrm{CH}_{2} \mathrm{CH}_{2}-\right)$, $0.9 \mathrm{l}\left(\mathrm{t}, 6 \mathrm{H} .-\mathrm{CH}_{3} . J=7.2 \mathrm{~Hz}\right)$.

1,8-Bis $(N$-butylureido)-4-nitronaphthalene (14). To a solution of $1,8-b i s(N$-butylureido)naphthalene $2(0.20 \mathrm{~g}$. $0.56 \mathrm{mmol}$ ) in dried $\mathrm{CH}_{2} \mathrm{Cl}_{2} 20 \mathrm{~mL}$ was added potassium nitrate $0.20 \mathrm{~g}(1.68 \mathrm{mmol})$ and aluminium chloride $0.30 \mathrm{~g}$ $(2.24 \mathrm{mmol})$ and the reaction mixture was stirred 2 hours in $0^{\circ} \mathrm{C}$ and stirred at the room temperature for 24 hours. The residue was treated with $5 \% \mathrm{HCl} 100 \mathrm{~mL}$. The precipitate was washed with $\mathrm{CHCl}_{3}(100 \mathrm{~mL})$ and filtered to give $0.15 \mathrm{~g}$ (66\%) of 14. mp $195^{\circ} \mathrm{C}$, decomp.: ${ }^{1} \mathrm{H}$ NMR (DMSO-di) $\delta$ $9.78(\mathrm{~s} . \mathrm{lH} . \mathrm{NH}), 8.58(\mathrm{~s}, \mathrm{lH}, \mathrm{NH}) .8 .25$ (three d. $3 \mathrm{H} . \mathrm{ArH}$ ), $7.64(\mathrm{~m} .2 \mathrm{H}, \mathrm{ArH}), 7.15(\mathrm{t}, 1 \mathrm{H}, \mathrm{NH}, J=5.3 \mathrm{~Hz}), 6.62(\mathrm{t}, \mathrm{lH}$. $\mathrm{NH} . J=5.6 \mathrm{~Hz}), 3.10\left(\mathrm{ml} .4 \mathrm{H} .-\mathrm{CH}_{2}-\right) .1 .41\left(\mathrm{~m} .8 \mathrm{H} .-\mathrm{CH}_{2} \mathrm{CH}_{2}-\right)$, 0.91 (two t. $6 \mathrm{H},-\mathrm{CH}_{3}$ ).

Acknowledgment. This work was supported by the Ministry of Education of Korea (BK 21 project).

\section{References}

1. Supramolecular Chemisty of Amons Bianchi, E.: BowmanJames. K.: Garcia-Espana. E.. Eds.:Wiley-VCH: New York. 1997.

2. Martinez-Manez. R.: Sancenon. F. Chent. Rev 2003. 103. 4419.

3. Kim. S. K.: Singh. N. J.: Kim. S. I.: Swamy. K. M. K.: Kim. S. H.: Lee. K. H.: Kim, K. S.; Yoon, J. Terahedron 2005, 61, 4545.

4. (a) Jose. D. A.; Kumar. D. K, Ganguly, B.: Das, A. Tetrahedron Lett. 2005, 46. 5343 , (b) Jose, D. A.: Kumar, D. K.: Ganguly, B: Das. A. Org. Lett. 2004. 6. 3445.

5. Reis. D. C.: Machado. C.: Machado. V. G. Tetrohedron Lent. 2006. +7.9339.

6. Kubik. S.: Revheller, C.: Stüwe, S. J. Inclusion Phenon Hacrocyd. Chem. 2005, 52. 137.

7. In. S.: Kang. J. Bull. Kowan Chem. Soc. 2005, 26. 1121

8. Dietrich. B. Pure Appl. Chem 1993. 65. 1457.

9. Atwood. T. L.: Holmant. K. I.: Steed. I. W. Chem. Commm. 1996. 1401 .

10. Gale. P. A. Coord Chem Rev 2001, 213. 79.

11. Beer. P. D.: Gale. P. A. Angen: Chem. Iht Ed. 2001. 40.486.

12. Cho. E. J: Yeo. H. M.: Ryu. B. J.: Jeong. H. A.: Nam, K. C. Bull. Korean Chem. Soc. 2006. 27. 1967.

13. Cho. E. J:: Moon. J. W.: Ko. S. W.: Lee. T. Y:: Kim. S. K.: Yoon. J. and Nam. K. C. J.Am. Chent. Soc. 2003. 125.12376.

14. Cho. E. J.; Ryu. B. J.: Lee, Y. J.: Nam, K. C. Org. Lett. 2005. 7, 2607.

15. Hynes. M. J. J. Chem. Soc. Dalton Trans. 1993. 311 